\title{
Performance of rose clover and hairy vetch interseeded into Old World bluestem
}

\author{
J.D. VOLESKY, D.P. MOWREY, AND G.R. SMITH
}

\begin{abstract}
Authors are assistant professor, University of Nebraska-Lincoln, West Central Research and Extension Center, Rt. 4, Box 46A, North Platte, Nebr. 69101 (at the time of the research, Volesky was with USDA-ARS Grazinglands Research Laboratory, El Reno, Okla.); research agronomist (deceased), USDA-ARS Grazinglands Research Laboratory, El Reno, Okla; and plant breeder, Texas Agricultural Experiment Station, Overton, Tex. 75684.
\end{abstract}

\begin{abstract}
Old World bluestems (Bothriochloa spp.) are extensively used throughout the Southern Plains. Interseeding these stands with persistent nitrogen-fixing legumes could reduce $\mathbf{N}$ fertilizer input, extend the grazing season, and enhance diet quality. The objective of this study was to evaluate production and persistence of 'Overton R18' and TXR20 rose clover (Trifolium hirtum All.) and hairy vetch (Vicia villosa Roth) when interseeded into Old World bluestem. Treatments included these interseeded annual legumes and bluestem $+100 \mathrm{~kg} / \mathrm{ha} \mathrm{N}$ fertilizer. Both rose clover and vetch produced a measurable quantity of forage by early spring before bluestem began to grow. Crude protein and in vitro dry matter digestibility were higher in legume treatments when legumes were actively growing. Total season forage production was similar $(6,460 \mathrm{~kg} / \mathrm{ha} ; \mathrm{P}>0.05)$ between rose clover and bluestem $+N$ treatments except during 1991 when production under the Overton R18 treatment was less than bluestem + N or TXR20 rose clover. Average rose clover seed production (26 $\mathrm{kg} / \mathrm{ha})$ was greater than vetch $(2 \mathrm{~kg} / \mathrm{ha} ; P<0.05)$ resulting in greater rose clover forage compared to vetch during natural reseeding years. Rose clover plant counts 4 years after the original seeding showed an average of 22 plants $/ \mathrm{m}^{2}$. Both rose clover entries appear to have excellent potential over previously available germplasm because of improved cold tolerance and the ability to produce substantial quantities of seed for natural reseeding even after close defoliation.
\end{abstract}

Key Words: Bothriochloa ischaemum L., persistence, production, Trifolium hirtum All., forage, Vicia villosa Roth, Southern Great Plains

Old World bluestems (Bothriochloa spp.) are the primary grasses being grown for improved warm-season pastures in the Southern Great Plains and have also been established extensively on marginal lands as part of the USDA Conservation Reserve Program (Berg 1990). Nitrogen fertilization is needed to realize the forage production potential of Old World bluestem; however, it is a significant input cost, an environmental concem, and can be inefficient duc to volatilization (Berg 1993). Absent in Old World bluestem pastures are persistent $\mathrm{N}$-fixing legumes that might decrease the need for fertilizer $N$ and offer other attributes such as extending the grazing season or enhancing diet quality.

Research has generally shown that, if initial legume establishment is successful, interseedings fail because of winter injury,

Published with the approval of the director of the Univ. of Nebraska-Lincoln Institute of Agr. and Natur. Resources, Agr. Res. Div. as Journal Ser. no. 11289.

Míanuscript accepted 3 Dec. 1995. summer drought, or poor self-reseeding mechanisms. Denman et al. (1961) evaluated 1,300 entries of 200 legume species in Oklahoma between 1951 and 1959 and reported that most clovers (Trifolium spp.) and medics (Medicago spp.) failed to survive winter stress. They concluded that only alfalfa (Medicago sativa L.) and some vetches (Vicia spp.) were of merit. Christiansen and Svejcar (1989) evaluated 22 medics and 8 subclovers (Trifolium subterraneum L.) in central Oklahoma and did not find any with significant forage production potential that would survive more than 1 year. Kneebone (1959) found little justification to use native legumes for interseeding in this region.

Rose clover ( $T$. hirtum All.), a winter-annual legume introduced into California in 1944 has become an important forage species in mild winter climatic zones (Drake et al. 1989). Because of a high percentage of hard seed, many stands have persisted for 4 decades in various soils, enduring drought and other stresses (Love 1985). Hard seed produced by rose clover become permeable to water at a slower rate than hard seed produced by subclovers or crimson clover ( $T$. incarnatum L.) (Williams and Elliott 1960). This persistent hard seed character in rose clover builds a soil seed bank and contributes to long-term stand maintenance and reliability in spite of drought and other environmental stresses (Love 1985).

Plantings of rose clover in the Southern Great Plains have consistently failed because of poor cold tolerance. Smith et al. (1986) initiated a rose clover breeding program with the objectives of developing productive rose clover varieties with late maturity, improved cold tolerance, and high levels of hard seed. Rose clover germplasm was produced that expressed these characteristics when compared with standard varieties. 'Overton R18' rose clover was released in 1991 by the Texas Agricultural Experiment Station in cooperation with the Soil Conservation Service (Smith et al. 1992). TXR20 is an experimental germplasm. Evers (1995) has successfully interseeded Overton R18 rose clover into bermudagrass sod [Cynodon dactylon (L.) Pers.] in northeast Texas but no information is available on interseeding into Old World bluestem. The objective of this research was to evaluate production and natural reseeding potential of these rose clovers and hairy vetch (Vicia villosa Roth) when interseeded into grazed bluestem stands.

\section{Materials and Methods}

The experiment was conducted during 1989 through 1993 at the USDA-ARS Grazinglands Research Laboratory near EI Reno, Okla. $\left(35^{\circ} 40^{\prime} \mathrm{N} 98^{\circ} 0^{\prime} \mathrm{W}\right.$; elevation $\left.=450 \mathrm{~m}\right)$. Soil type for the 
experiment was a Dale silt loam (fine-silty, mixed, thermic, Udic Paleustolls). Mean annual precipitation is $810 \mathrm{~mm}$, of which about $70 \%$ is received from April through September. Annual precipitation in 1990, 1991, 1992, and 1993 was 877, 744, 941, and $948 \mathrm{~mm}$, respectively. In 1989, the seeding year, temperatures decreased to record lows during much of December with a minimum of $-27^{\circ} \mathrm{C}$.

Three legume-interseeded treatments and 1 grass $+N$ treatment were imposed on established stands of 'Plains' Old World bluestem [Bothriochloa ischaemum (L.) Keng]. Inoculated seed of Overton R18 and TXR20 rose clover and hairy vetch was planted in $18 \mathrm{~cm}$ rows at rates of 12 and $20 \mathrm{~kg} / \mathrm{ha}$ for the rose clovers and vetch, respectively. Planting was done with a no-till drill on 13 October 1989. Nitrogen fertilizer ( $100 \mathrm{~kg} \mathrm{~N} / \mathrm{ha}$ ) was broadcast on the bluestem $+\mathbf{N}$ treatment during late April of 1990,1991 , and 1992. Because of dry fall conditions, 33 and 38 $\mathrm{mm}$ of irrigation water were applied in October of 1989 and 1990 , respectively.

All plots $(5 \times 18 \mathrm{~m})$ were grazed for 1 week with steers beginning 7 May, 29 May, 16 July, and 22 August 1990; 18 April, 16 May, 18 June, and 22 July 1991; and 22 April, 19 May, and 17 July 1992. Phenologically, legume growth stage at the first grazing was vegetative. At the second grazing, legumes were at early bloom and the bluestem was vegetative; and at later harvests the legumes were senescent and the bluestem was at boot stage or headed. Stubble height after grazing averaged $6.4 \mathrm{~cm}$.

Forage production was measured in 3 randomly selected 0.25 $\mathrm{m}^{2}$ quadrats per plot before each grazing event. Forage was handclipped to ground level and dried in a forced-air oven at $65^{\circ} \mathrm{C}$ for 2 days. Forage from quadrat samples was hand separated to quantify legume and bluestem proportions. Components were recombined and then ground in a shear mill to pass a $2-\mathrm{mm}$ screen. A $100-\mathrm{g}$ subsample was reground in a centrifugal mill to pass a 1$\mathrm{mm}$ screen; then analyzed for digestibility using an in vitro rumen fermentation procedure developed by Tilley and Terry (1963) and modified by Monson et al. (1969). Nitrogen content was determined using a LECO CHN-1000 Elemental Analyzer ${ }^{1}$ and crude protein expressed as N X 6.25.

Legume seed production was measured by hand harvesting three $0.25-\mathrm{m}^{2}$ quadrats per plot when seed was ripe in 1990 , 1991, and 1992. All plots were periodically grazed during 1993 without any sampling except plant counts (six $0.25-\mathrm{m}^{2}$ quadrats/plot) made of the legumes in November.

All treatments were replicated 3 times. Data were subjected to repeated measures analysis of variance (SAS Institute Inc. 1985). Years were considered a fixed effect and treated as a split-plot in time. Where needed, LSD $(P<0.05)$ was used for treatment mean separation.

\section{Results and Discussion}

\section{Forage Production}

The year by treatment interaction for early spring forage production was significant $(\mathrm{P}<0.01)$ with legume production declining over years (Fig. 1). Average forage production in the legume treatments at the first grazing in 1990 was $1,750 \mathrm{~kg} / \mathrm{ha}$. Both rose clovers

\footnotetext{
'LECO Corporation, 3000 Lakeview Ave., St. Joseph, Mich. 49085-2396. Mention of trade names or propriety products does not indicate endorsements by the USDA, and does not imply its approval to the exclusion of other products that may also be suitable.
}

and vetch increased early spring forage yields $(P<0.05)$ over the bluestem $+\mathrm{N}$ treatment. Among legumes during 1990 , vetch production was greater than either of the rose clovers $(P<0.05)$. By 1991 however, production under the vetch treatment dropped to $270 \mathrm{~kg} / \mathrm{ha}$ and to $30 \mathrm{~kg} / \mathrm{ha}$ in 1992 due to the failure of vetch to naturally reseed. TXR20 rose clover production was significantly greater than Overton R18 only during $1991(\mathrm{P}<0.05)$. Evers $(1995)$ reported dry matter production of Overton R18 rose clover to be about 2,660 $\mathrm{kg} / \mathrm{ha}$ in northeast Texas using the same seeding rate as in this study.

Forage produced at the first grazing was generally above $80 \%$ legume with the remainder primarily annual cool-season grasses (Fig. 2). At the second grazing, bluestem had begun growth and represented about $50 \%$ of the forage biomass except in the vetch treatment during 1991 and 1992 when vetch growth was dependent on natural reseeding. Biomass from third and fourth harvests was greater than $90 \%$ bluestem across treatments.

The year by treatment interaction for total season forage production was also significant $(\mathrm{P}<0.01$; Fig. 3 ). Total forage production in 1990 was similar among legume treatments $(P>0.05)$; however, vetch production was significantly greater than that of bluestem $+N(P<0.05)$. Bluestem $+N$ and TXR20 rose clover treatments had total forage production greater than Overton R18 and vetch during 1991. During 1992, total forage production was similar between both rose clovers and the bluestem $+\mathrm{N}$ treatment but greater than the vetch treatment $(\mathrm{P}<0.05)$.

\section{Legume Persistence}

The hairy vetch and both rose clovers appeared adapted to this environment and did not succumb to cold or other stress. All legumes were readily grazed by the steers and no grazing preferences were observed.

Rose clover exhibited an advantage $(\mathrm{P}<0.05)$ in forage production during the second and third years through natural resecding compared with vetch (Fig. 1 and 2). Second and third year stands of vetch declined in production as a result of that species failing to naturally reseed under our grazing management. Only a small number of vetch plants were observed flowering and setting seed between grazing events. Rose clover growth, however, after the second grazing (mid-May) included many seed heads borne 4 to

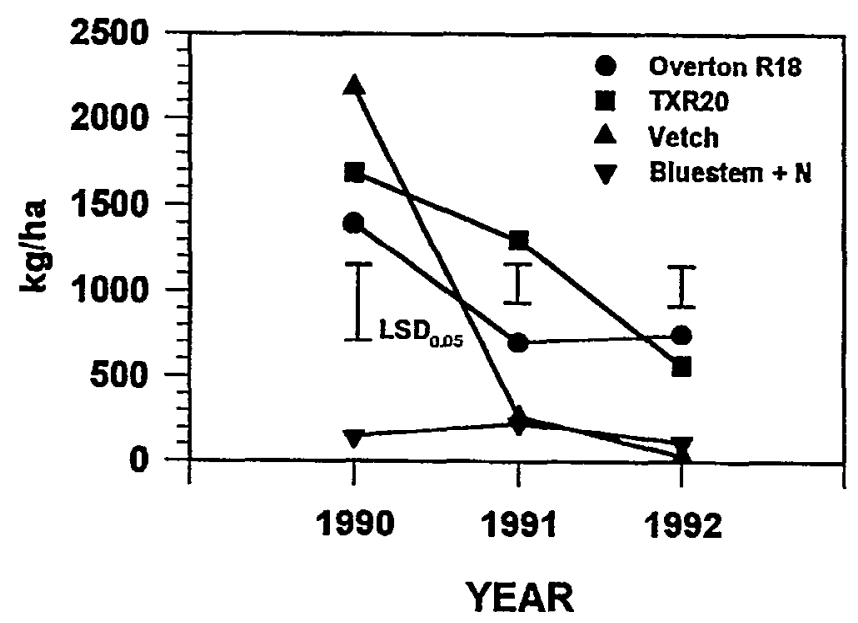

Fig. 1. Early spring (legume vegetative) forage production during 1990,1991 , and 1992. Year by treatment interaction was significant at $P<0.01$. 

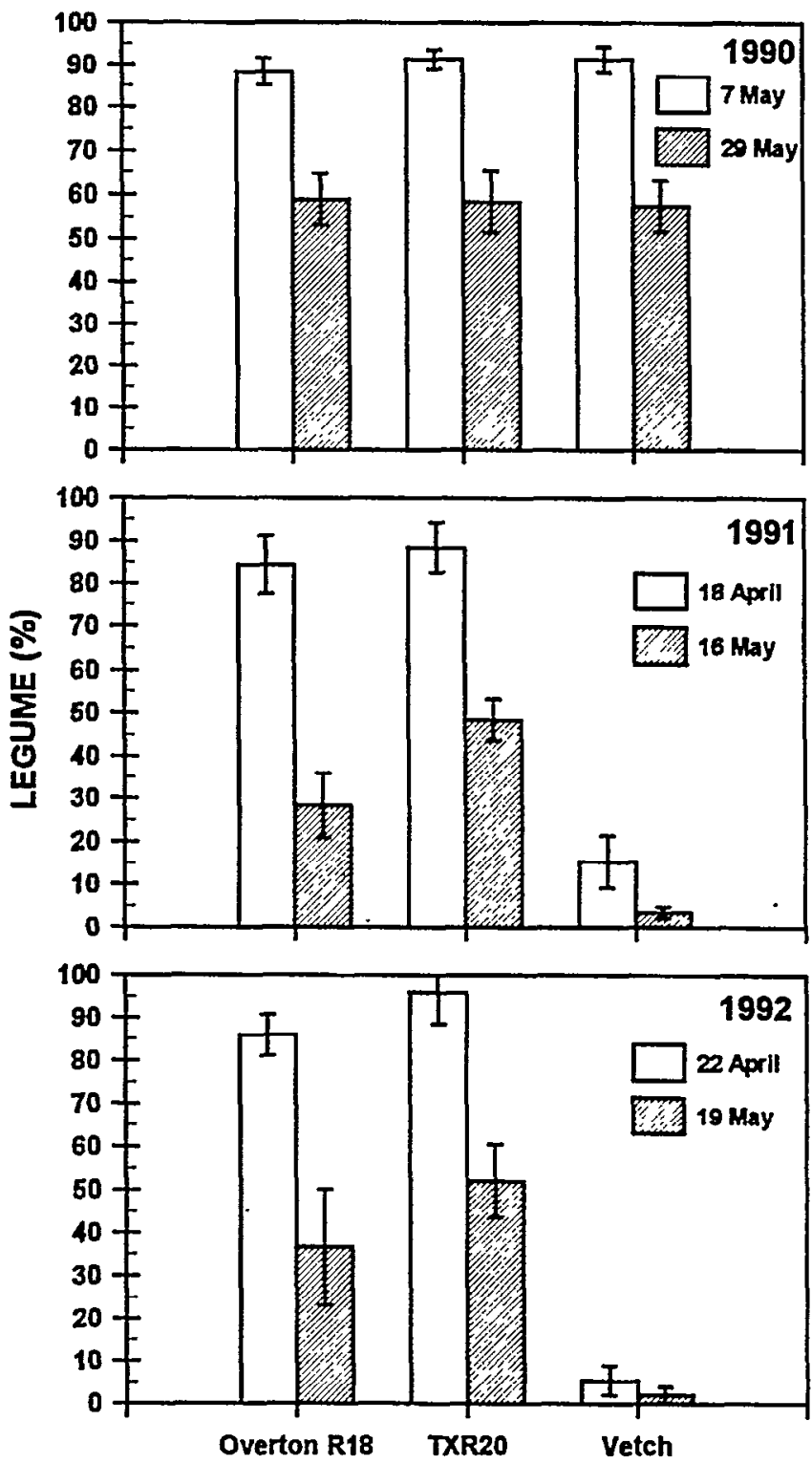

TREATMENT

Fig. 2. Legume percentage ( $+\mathrm{SE})$ of the available forage at the 2 spring grazing dates during 1990, 1991, and 1992.

$8 \mathrm{~cm}$ from the soil surface. At the third grazing date, seed heads were generally under the grass canopy and not selected by steers. Most rose clover plants matured and began to drop seed from mid- to late June.

Rose clover seed production averaged 40,37 , and $0.5 \mathrm{~kg} / \mathrm{ha}$ in 1990, 1991, and 1992, respectively. Dry conditions during April and May of 1992 may have contributed to the lower seed and spring forage production that year. The seed averaged $87 \%$ hard seed, which indicates about a $5 \mathrm{~kg} / \mathrm{ha}$ natural seeding rate the first year after production. A substantial number of rose clover plants were present in 1993 following the poor seed production year of 1992 , indicating regeneration through hard seed. Plant counts in November 1993 showed $21.6 \mathrm{plants} / \mathrm{m}^{2}$ with no significant differences $(P>0.05)$ between Overton R18 and TXR20 rose clovers. Plant counts of vetch at this date indicated only $2.4 \mathrm{plants} / \mathrm{m}^{2}$.
Seed produced from rose clover contains at least $80 \%$ hard seed that will not germinate for at least a year (Young et al. 1973). Ripe rose clover seed, when ingested by cattle and then passed, have remained viable in the manure for 23 years, with some seeds germinating each year when conditions were right (Helphinstine et al. 1983).

Vetch seed production was lower $(\mathrm{P}<0.05)$ than rose clover and averaged $2 \mathrm{~kg} / \mathrm{ha}$ across years. Vetch would need to be managed to produce a seed crop periodically or have to be sown annually. In this study, management for a seed crop was not an objective. For an annual legume to persist in most grazing situations, seed production under close grazing would be beneficial. For rose clover, which has seedling vigor described as poor (Evers 1993), its ability to produce a large seed crop with a high percentage hard seed would be advantageous.

\section{Forage Nutritive Value}

Significant year by treatment interactions existed for both crude protein and in vitro dry matter digestibility (Table $1 ; P<0.01$ ). Crude protein of available forage in legume treatments at the first grazing (legume vegetative) in 1990 was significantly higher $(P<0.05)$ than that of bluestem $+\mathrm{N}$ treatment. Low crude protein in the bluestem + $\mathrm{N}$ treatment could be attributed to a higher proportion of aftermath from the previous season. Crude protein of forage in the vetch treatment at the initial sampling was also higher than rose clover. In 1991 and 1992, treatment differences at the first grazing were not as pronounced. An abundance of cool-season annual grasses in the bluestem $+\mathrm{N}$ treatment probably enhanced crude protein, but the quantity of early spring forage was small in that treatment (Fig. 1). By the second grazing period (legume flowering/bluestem vegetative) in all 3 years, differences in crude protein among treatments were generally small.

The presence of legumes enhanced in vitro dry matter digestibility of available forage, particularly during the first grazing period in 1990 (Table 1). Digestibility during the first grazing period on legume treatments averaged $76.5 \%$, compared with only $46 \%$ on the bluestem $+N$ treatment $(P<0.05)$. Within years, differences in digestibility at the second grazing were less among treatments even though the forage biomass varied considerably in percent legume. At this time the bluestem was vegetative and nearly equal in digestibility to the legume. Digestibility at later grazing dates declined but was not different among treatments $(P>0.05)$.

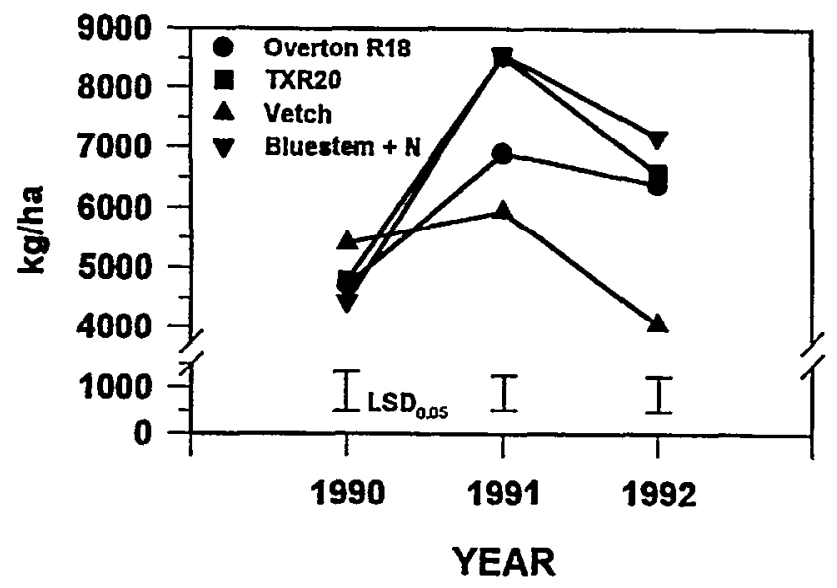

Fig. 3. Season total forage production during 1990, 1991, and 1992. Year by treatment interaction was significant at $\mathbf{P}<0.01$. 
Table 1. Crude protein (CP) and in vitro dry matter digestibility (IVDMD) of available forage at the first and second grazing periods.

\begin{tabular}{|c|c|c|c|c|c|c|}
\hline \multirow[t]{2}{*}{ Treatment } & \multicolumn{2}{|c|}{1990} & \multicolumn{2}{|c|}{1991} & \multicolumn{2}{|c|}{1992} \\
\hline & $\mathbf{C P}$ & IVDMD & $\mathrm{CP}$ & IVDMD & $\mathbf{C P}$ & IVDMD \\
\hline & \multicolumn{6}{|c|}{ 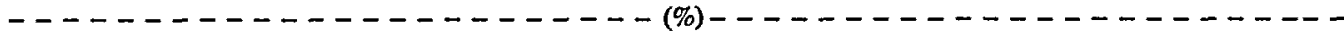 } \\
\hline \multicolumn{7}{|c|}{ First grazing period $^{1}$} \\
\hline Bluestem $+\mathrm{N}$ & $6.7 \mathrm{c}$ & $46.0 \mathrm{~b}$ & $16.8 \mathrm{~b}$ & $60.8 b$ & $12.0 \mathrm{c}$ & $56.1 \mathrm{~b}$ \\
\hline Overton R18 & $16.9 \mathrm{~b}$ & $76.3 a$ & 19.2a & $69.3 \mathrm{a}$ & $15.3 \mathrm{~b}$ & $77.7 \mathrm{a}$ \\
\hline TXR20 & $17.1 \mathrm{~b}$ & $77.3 a$ & $20.0 \mathrm{a}$ & $69.7 \mathrm{a}$ & $14.9 \mathrm{~b}$ & $78.0 \mathrm{a}$ \\
\hline Vetch & $25.0 \mathrm{a}$ & $75.8 \mathrm{a}$ & 21.0a & $58.6 \mathrm{~b}$ & $20.6 \mathrm{a}$ & $57.2 \mathrm{~b}$ \\
\hline Overton R18 & $16.1 \mathrm{~b}$ & $68.0 \mathrm{a}$ & 18.1b & 66.6 & 12.6 & 61.6ab \\
\hline TXR20 & $16.6 \mathrm{~b}$ & $67.3 \mathrm{a}$ & $17.2 b$ & 66.5 & 11.5 & $63.7 \mathrm{a}$ \\
\hline Vetch & $19.1 \mathrm{a}$ & $69.7 a$ & $21.9 \mathrm{a}$ & 68.2 & 12.5 & $57.4 c$ \\
\hline
\end{tabular}

Legumes vegetative during first grazing period.

${ }^{2}$ Legumes flowering and bluestem vegetative during second grazing period.

${ }^{a b s}$ Within years and grazing, treatment means of CP or IVDMD with unlike superscripts significantly differ $(P<0.05)$.

The overall nutritive value of the forage tested in this study compares well to early bloom alfalfa which normally will range from 60 to $65 \%$ digestibility (Matches et al. 1970). Enhancement in forage quality primarily occurred when the legumes were productive in the spring. Rose clover and vetch had minimal effect on the quality of the forage once bluestem began growth.

\section{Conclusions}

The vetch and rose clovers evaluated in this experiment offered increased early spring forage production of high nutritive value when interseeded into Old World bluestem pasture. Both rose clovers appear to have excellent potential over previously available cultivars because of improved cold tolerance and the ability to produce seed for natural reseeding even after close defoliation. Grazing management to periodically produce a seed crop or resceding may be beneficial to regenerating rose clover; however, it appears these practices are mandatory for vetch.

Total season forage production was similar between rose clover and bluestem $+\mathrm{N}$ treatments during all 3 years with the exception of Overton R18 during 1991. The bluestem $+\mathrm{N}$ treatment did produce more summer forage than legume treatments. Nitrogen fixation or water use trends were not investigated in this study and early season soil water use by the legumes could have limited bluestem production. Bluestem persistence was excellent under all treatments. Dense legume canopies can shade out bluestem as it begins growth and consequently reduce bluestem stand vigor. This emphasizes the need for grazing management strategies that will effectively utilize the legume forage during the spring and reduce the shading effect. Direct annual legume and bluestem competition is eliminated in early summer when the legumes die. This is an advantage in drier climates compared to perennial legumes that would compete for nutrients and soil water throughout the growing season. As a reseeding annual, rose clover appears well suited to the drier areas of the Southern Plains, primarily because its spring growth coincides with the period likely to have the greatest precipitation. Fall growth of rose clover seedlings, however, was slow and many had a weak appearance, particularly during extended dry periods. October and November precipitation was 45 and $54 \%$ of the long-term average in 1989 and 1990, respectively. The irrigation water that our treatment plots received in October 1989 and 1990 was of the amount that any deviations from the long-term average were nearly eliminated. Further work is needed without fall irrigation to extend our findings.

\section{Literature Cited}

Berg, W.A. 1990. Old world bluestem responses to nitrogen fertilization. J. Range Manage. 43:265-270.

Berg, W.A. 1993. Old world bluestem response to fire and nitrogen fertilizers. J. Range Manage. 46:421-425.

Christiansen, S. and T.J. Svejcar. 1989. Evaluation of annual medics and subclovers in Oklahoma. p. 239-240. In: Proc. XVI Int. Grassl. Congr. Nice, France.

Denman, C.E., W.L. Richardson, and J.R. Harlan. 1961. Legume adaption studies in north central Oklahoma. Okla. Agr. Exp. Sta. Bull. B-587. $11 \mathrm{p}$.

Drake, D.J., R.W. Benton, H. Carlson, and W.L. Graves. 1989. Cold-tolerant rose clovers. Califomia Agr. 43:16-19.

Evers, G.W. 1993. Weed control on warm-season perennial grass pastures with clovers. Crop Sci. 23:170-171.

Evers, G.W. 1995. Methods of rose clover establishment into bermudagrass sod. J. Prod. Agr. 8:366-368.

Helphinstine, W.N., V.W. Brown, and R.M. Love. 1983. Hard seed ensures rose clover survival. California Agr. 37:12-13.

Kneebone, W.R. 1959. An evaluation of legumes for western Oklahoma rangelands. Okla. Agr. Exp. Sta. Bull. B-589. 13 p.

Love, R.M. 1985. Rose clover. p. 535-546. In: N.C. Taylor (ed.) Clover science and technology. Agron. Monogr. 25. ASA, CSSA, and SSSA, Madison, Wis.

Matches, A.G., W.F. Wedin, G.C. Marten, D. Smith, and B.R. Baumgardt. 1970. Forage quality of Vernal and DuPuits alfalfa harvested by calendar date and plant maturity schedules in Missouri, Iowa, Wisconsin, and Minnesota. Res. Rep. 73, Coll. of Agr. and Life Sci., Univ. of Wisconsin. $20 \mathrm{p}$.

Monson, W.G., R.S. Lowrey, and I. Forbes, Jr. 1969. In vitro nylon bag vs. two-stage in vitro digestion: Comparison of two techniques for estimating dry-matter digestibility of forages. Agron. J. 83:714-716.

SAS Institute Inc. 1985. SAS user's guide: statistics. (Version 5 ed.), SAS Institute Inc. Cary, N.C.

Smith, G.R., G.W. Evers, T.J. Gerik, E.C. Holt, M. Hussey, W.R. Ocumpaugh, J.C. Read, and A.M. Schubert. 1986. Evaluation of experimental rose clover at eight Texas locations. Forage Research in Texas. TAES CPR 4499:45-47.

Smith, G.R., F.M. Rouquette, Jr., G.W. Evers, M.A. Hussey, W.R. Ocumpaugh, J.C. Read, and A.M. Schubert. 1992. Registration of 'Overton R18' rose clover. Crop Sci. 32:1507.

Tilley, J.M.A. and R.A. Terry. 1963. A two-stage technique for the in vitro digestion of forage feeds. J. Brit. Grassl. Soc. 18:104-111.

Williams, W.A. and J.R. Elliot. 1960. Ecological significance of seed coat impermeability to moisture in crimson, subterranean and rose clovers in a Mediterranean-type climate. Ecology 41:785-790.

Young, J.A., R.A. Evans, and B.L. Kay. 1973. Temperature requirements for seed germination in an annual-type rangeland community. Agron. J. 65:656-659. 